\title{
Living With Volcano Hazards
}

\begin{tabular}{|l||}
\hline \hline Eolcanic eruptions are among \\
Earth's most dramatic and \\
powerful agents of change. Ash, \\
mudflows, and lava flows can devastate \\
communities near volcanoes and \\
cause havoc in areas far downwind, \\
downstream, and downslope. Even \\
when a volcano is quiet, steep volcanic \\
slopes can collapse to become \\
landslides, and large rocks can be \\
hurled by powerful steam blasts. \\
Hazardous volcanic conditions might \\
last for a day or decades, all the while \\
threatening people's health and safety. \\
Scientists with the U.S. Geological \\
Survey and partner agencies assess \\
hazards and closely monitor activity at \\
the Nation's volcanoes. They provide \\
volcano updates and warnings of \\
hazardous situations, as well as \\
guidance on actions to take. You can \\
prepare your family and community by \\
familiarizing yourself with the types of \\
hazards at volcanoes near where you \\
live and visit. \\
\hline
\end{tabular}

The grandeur of volcanoes, whether capped by snow, covered by forests, or rocky and barren, often fails to hint at activity deep underground. Beneath an active volcano, rising magma (underground molten rock) generates earthquakes as it exerts pressure on and fractures surrounding rock. These fractures create pathways for rising heat, volcanic gases, and magma. Just below the surface, groundwater boils to steam. When magma reaches the surface a variety of eruption processes can occur. At some volcanoes, tiny shards of rock can be blasted skyward in columns of ash and steam. Lava can be pushed out of the ground as thick flows or pile up into steep-sided mounds. At other volcanoes, more-fluid lava might fountain into the air in a spectacular incandescent display and then flow quickly across the ground. With each new series of eruptions, the shape of a volcano changes, growing more massive or catastrophically collapsing. Even when activity stops, potentially hazardous change continues as water scours loose volcanic debris and transports it far down river valleys.
The eruption and erosion processes that shape volcanoes are an ever-present threat. This fact sheet describes volcanic hazards and their impacts at two common types of volcanoes - stratovolcanoes and shield volcanoes. Volcano terms, shown in bold, are explained in two large graphics. Using the information in this fact sheet and the internet resources on page 6 , you can learn more about volcanoes and how to prepare for future activity.

\section{Volcano Hazards Are Location Dependent- Heed Emergency Advice}

Volcano hazards have the potential to cause great harm and destruction, but whether or not you will be affected depends on the type of volcano (stratovolcano or shield volcano), the specific hazard, and your location relative to it. In all instances, heed the advice of emergency officials!

In this nightime view, Mount Shasta, a stratovolcano of the Cascade Range, rises above the town of Weed in northern California — one of four small towns around the base of the volcano. This region is in the center of major interstate, rail, and air transportation corridors on the West Coast. (Copyrighted photograph by Mark Stensaas, used with permission.) 


\section{Stratovolcanoes}

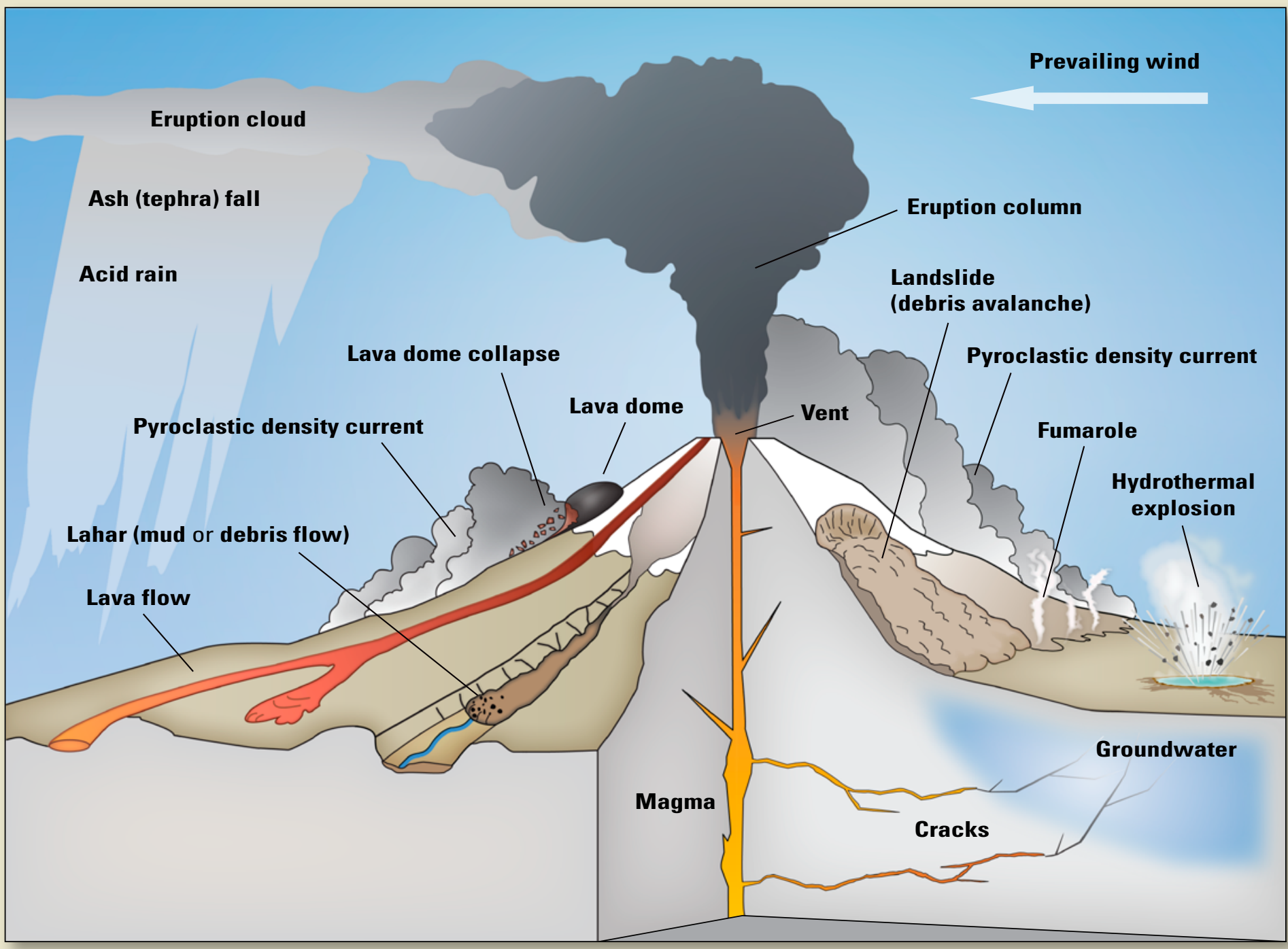

Stratovolcanoes are tall, cone-shaped, and often glaciated volcanoes that tend to erupt explosively. In the Western United States, they are located in Alaska, Washington, Oregon, and northern California. Eruptions can proceed in the following sequence, but these events may occur independently. Magma (underground molten rock) rises from deep below the volcano, and (1) explosive eruptions blast volcanic debris (tephra) into the sky, forming an eruption column and cloud. (2) The ash cloud cools and drifts downwind, and ash falls to the ground at local air temperature. (3) Lava flows move downslope or form lava domes at the erupting vent. (4) Eruption columns, lava flows, or lava domes collapse, creating hot pyroclastic density currents.

(5) These can melt snow and ice or enter rivers to create lahars. Even when a volcano is not erupting, landslides or debris avalanches can occur due to gravity. At stratovolcanoes and caldera systems that host hot springs, fumaroles, and other thermal features, hot rock and steam blasts called hydrothermal explosions can occur at any time. Caldera systems are large volcanic centers usually characterized by a massive central crater, like at Long Valley in California and in the Wyoming part of Yellowstone National Park.

\section{Avoid Hazards and Heed Official Advice}

- Lava flows, pyroclastic density currents, landslides, and rockfalls seldom travel far beyond a stratovolcano's base. At the volcano, tephra fall will include large hot blocks of rock, and dangerous concentrations of volcanic gases can collect in caves. At actively outgassing volcanoes, avoid low and confined areas where dangerous gases might accumulate.

- Volcanic ash can fall tens to even thousands of miles away from an eruption. Avoid travel and reduce exposure by staying indoors. When exposed to intense falling or windblown ash, use protective breathing devices, such as masks.

- Lahars are a hazard on volcanic slopes and to downstream communities tens of miles from a volcano. If you receive a public emergency notification of a lahar, or otherwise recognize its approach, get off valley floors to higher ground as quickly and safely as possible. 


\section{Eruption Clouds and Ashfall-The Most Widespread Volcano Hazards}

Explosive eruptions originate at volcanic vents and blast tephra (rock and volcanic glass fragments) and volcanic gases into the air with tremendous force. An eruption column can reach more than 12 miles above a volcano in less than 30 minutes. The column rises and spreads to form an eruption cloud. Volcanic ash particles (those smaller than about 0.08 inch in diameter) within the column and cloud are highly charged and generate lightning and thunder. The eruption cloud can extend thousands of miles downwind and rain gritty ash over vast regions. The largest tephra pieces fall near the vent, whereas the wind blows cooled volcanic ash great distanceseven around the world.

Volcanic ash is a threat to people, agriculture, aviation, ground transportation, and communications and utility systems. For both ground and air transportation, ash reduces visibility, short-circuits electronic equipment, and damages engines - jet aircraft are particularly vulnerable. Flight delays and cancellations can interrupt delivery of goods and supplies. Accumulation of ash several inches thick, especially when wet, can collapse roofs, clog wastewater systems, and reduce the quality of drinking water. Even minor ashfall can harm crops, electronics, and

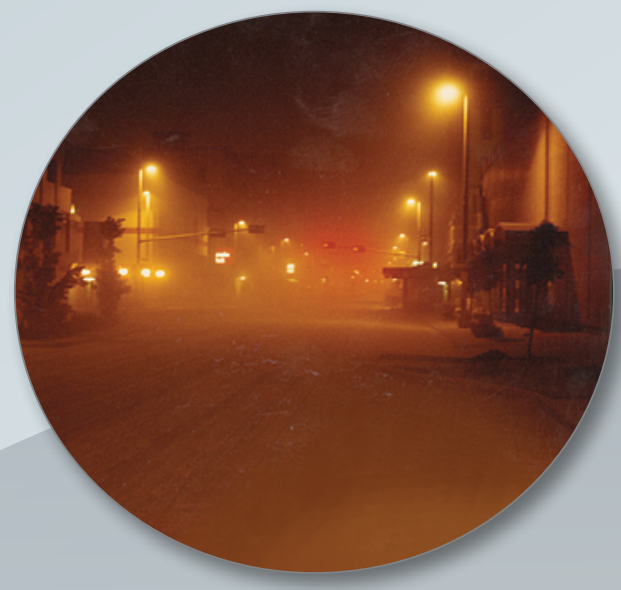

Ashfall from the May 18, 1980, eruption of Mount St. Helens, Washington, blocked the sun causing street lights to turn on at 1:30 p.m. along Yakima Avenue in Yakima, Washington. Over several hours, Yakima received about one-half to three-quarters of an inch of ashfall. It choked the city with a stubborn cloud of suspended particles that made breathing difficult and driving nearly impossible. Ash affected the lives and businesses of the 50,000 residents for months. (Photograph copyright Yakima Valley Museum, used with permission.) machinery and is a health hazard to humans and animals.

\section{Lava Flows Consume Everything in Their Way}

Lava flows are molten rock and ooze onto the Earth's surface from a volcanic vent. Stratovolcanoes, such as the large cone-shaped volcanoes in the Pacific Northwest and Alaska, often erupt viscous lava that flows like toothpaste. Thick and sluggish lava may travel a mile or more downslope. When flows of extremely viscous lava pile up around a vent, they build a lava dome. The thick and rubbly edges of new lava flows and domes can collapse to form hot, fast-moving pyroclastic density currents.

Shield volcanoes, like those in the State of Hawaii, erupt less-viscous lava that flows like warm honey. These lava flows travel as glowing orange rivers or creep across terrain as shimmering silver masses that sprout lobes of red liquid rock. Lava can flow as fast as 30 miles per hour ( $\mathrm{mi} / \mathrm{hr}$ ) on steep slopes but at less than $1 \mathrm{mi} / \mathrm{hr}$ on gentle slopes. Lava is erupted directly from open vents as flows or lava fountains (jets of low-viscosity lava sprayed into the air).

Anything in the way of an advancing lava flow will be surrounded, buried, or burned by extreme heat (as high as 2,100 degrees Fahrenheit, ${ }^{\circ}$ F). Lava flows also create secondary hazards

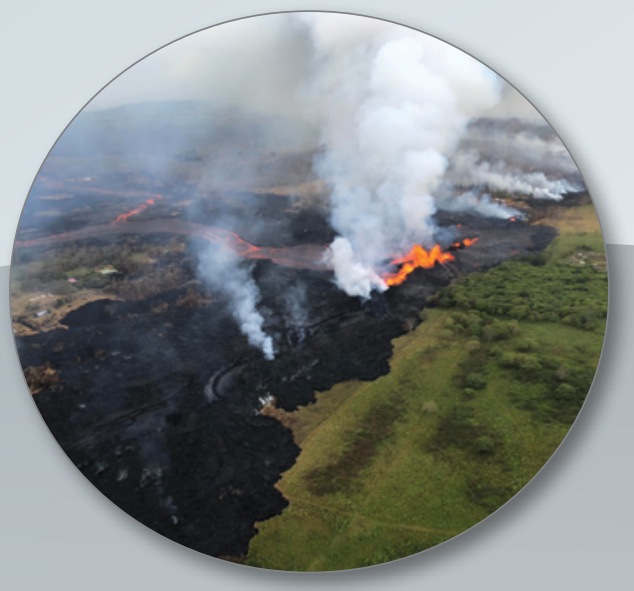

Lava flows have destroyed more than 900 structures on the Island of Hawai'i since 1983. In May 2018, erupting fissures opened along Kīlauea Volcano's lower East Rift Zone and sent rivers of lava through residential subdivisions and farmland. For 3 months, sulfur dioxide and other volcanic gases billowed out of open vents, killing vegetation immediately downwind of the fissure system. As the gases drifted farther away, vog (volcanic smog) created poor air quality that caused breathing and health problems for people not only on Hawai'i, but also in Honolulu nearly 250 miles away on the Island of 0 'ahu. (Photograph by Volcano Helicopters, used with permission.) such as fires, methane explosions, and dangerous conditions where they enter bodies of water. Fortunately, lava flows typically travel slowly enough that people can avoid contact.

\section{Pyroclastic Density Currents Are Hot, Fast, and Destructive}

The term pyroclastic density current refers to a family of ground-hugging avalanches of hot gases and dry boulderto-ash-size rock fragments that rush down volcanic slopes at speeds that can exceed $220 \mathrm{mi} / \mathrm{hr}$. They originate as viscous lava flows, domes, and eruption columns that collapse and then roar downward. Rock-rich pyroclastic flows typically follow channels and valleys. Gas-rich pyroclastic surges are more mobile and spread unpredictably over valleys and hills. Flows may reach more than 10 miles from the source and leave deposits that range in thickness from a fraction of an inch on hillslopes to more than 700 feet in deep valleys. The extreme temperatures of such flows (as high as $1,500^{\circ} \mathrm{F}$ ) can cause fires and melt snow and ice, which may mix to generate lahars (see page 5).

As pyroclastic density currents spread, they knock down, shatter, burn, bury, and (or) carry away nearly everything in their paths. People and animals may be killed or seriously injured from burns and inhalation of hot ash and gases.

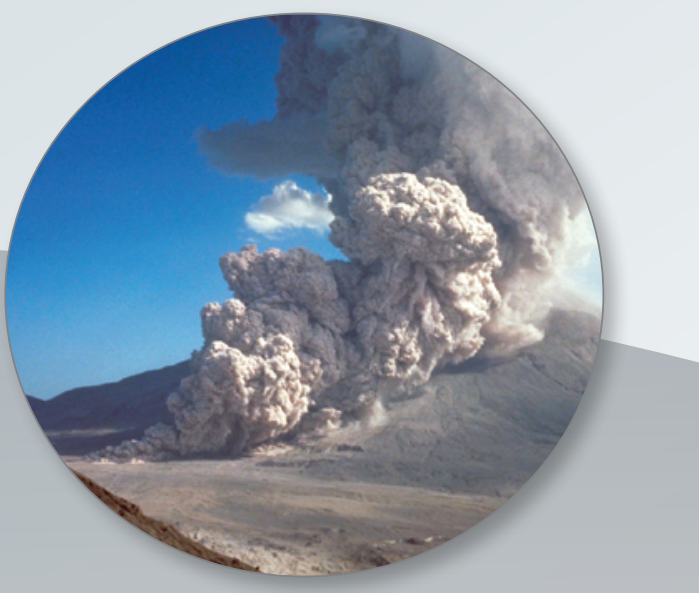

On August 7, 1980, a small explosive eruption occurred in the crater of Mount St. Helens, Washington. The eruption generated a pyroclastic density current that swept down the volcano's north flank. (U.S. Geological Survey photograph by Peter Lipman.) 


\section{Shield Volcanoes and Lava Fields}

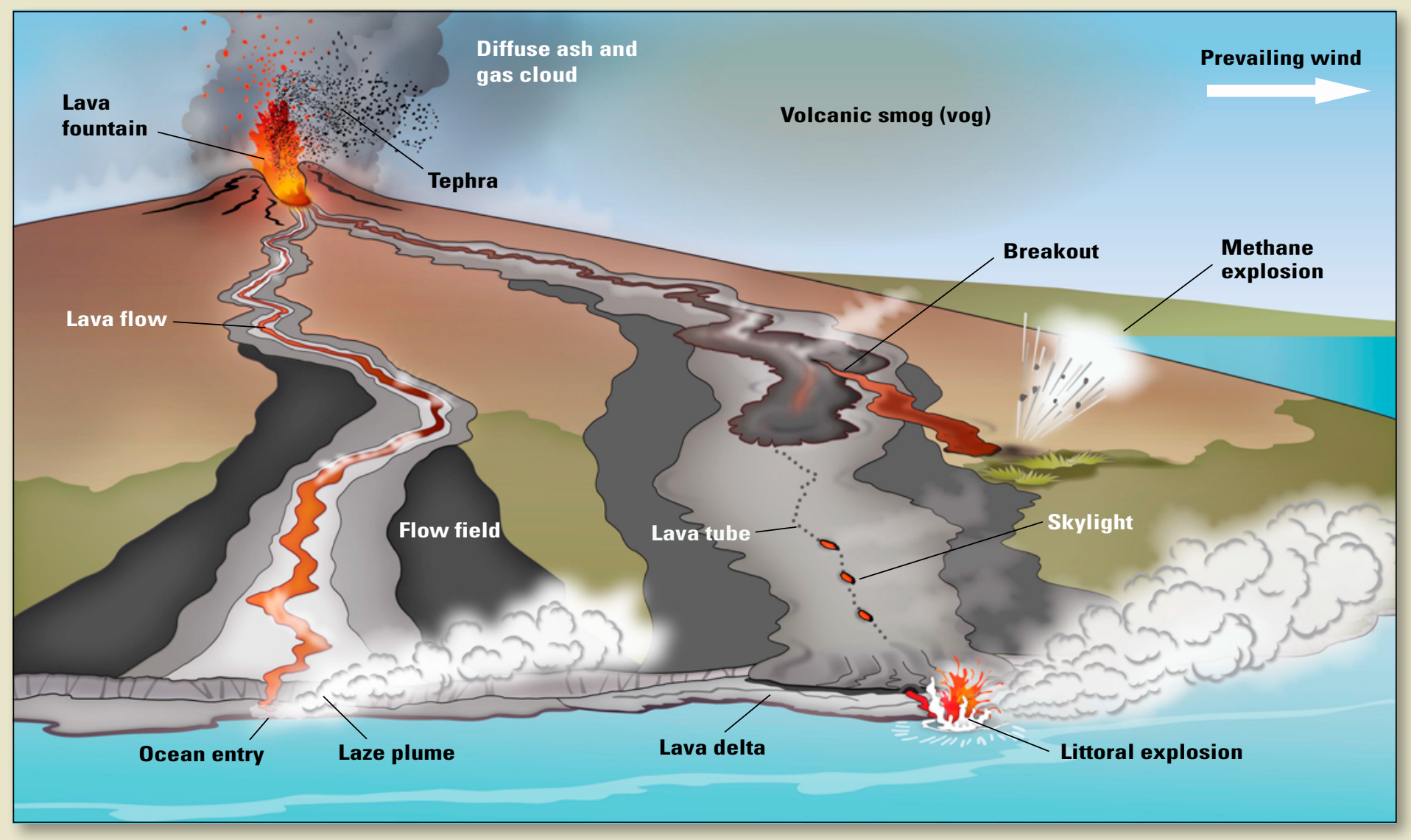

Shield volcanoes have a broad, shield shape and tend to erupt fluid lava that can travel many miles, but violent explosive eruptions are also possible. Hawaiian volcanoes are the quintessential shield volcanoes. Lava fields, which erupt in the same way, are found in nearly every State west of the Rocky Mountains. Most eruptions begin as a vertical sheet (dike) of rising magma that discharges from groups of aligned vents, called fissures, which can extend for miles. (1) Low lava fountains jet skyward, and lava fragments cool to tephra as they fall. Activity may localize at a single vent and grow more energetic to produce a diffuse ash and gas cloud that drifts downwind. (2) Emission of volcanic gas can produce volcanic smog (vog). (3) Lava flows can travel long distances, sometimes underground within insulating lava tubes. When the roofs of tubes break, open skylights are created, allowing heat and fumes to escape. (4) Lava can pour from a vent for months or years to form a lava flow field that can feed breakouts of new lava flows. (5) When lava buries vegetation, intense heat cooks plant matter, producing gas, and sudden methane explosions can violently toss large rocks tens of feet into the air. (6) Lava entering the ocean (ocean entry) or a body of water creates new, unstable land called a lava delta that can explosively collapse into the sea. Lava entering cold ocean water

The San Francisco Volcanic Field is an area of young volcanoes in northern Arizona's Colorado Plateau region that covers 1,800 square miles. At the north end of the field, several cinder cones surround SP Crater ( 820 feet high), which is a picturesque example of a cinder cone and associated lava flow (shown here). The flow extends to the north 4.3 miles from SP Crater, where it originated, and is about 100 feet thick. The most recent eruption from the field was at Sunset Crater (about 17 miles to the south) in about A.D. 1085. (Copyrighted photograph by Michael Collier, used with permission.) typically causes littoral explosions-hot seawater and acidic clouds of gas, steam, and volcanic glass that blow downwind as a laze plume.

\section{Avoid Hazards and Heed Official Advice}

- Lava flows can travel tens of miles. Lava deltas can catastrophically collapse and blast large rocks hundreds of feet into the air. Hazardous fumes at lava water-entry sites can make breathing difficult. Stay a safe distance away from lava deltas and active lava flows.

- During an eruption or vigorous gas emission, vog spreads with the wind and can affect areas hundreds of miles from the volcano. Check local air-quality conditions and heed warnings and posted signs.

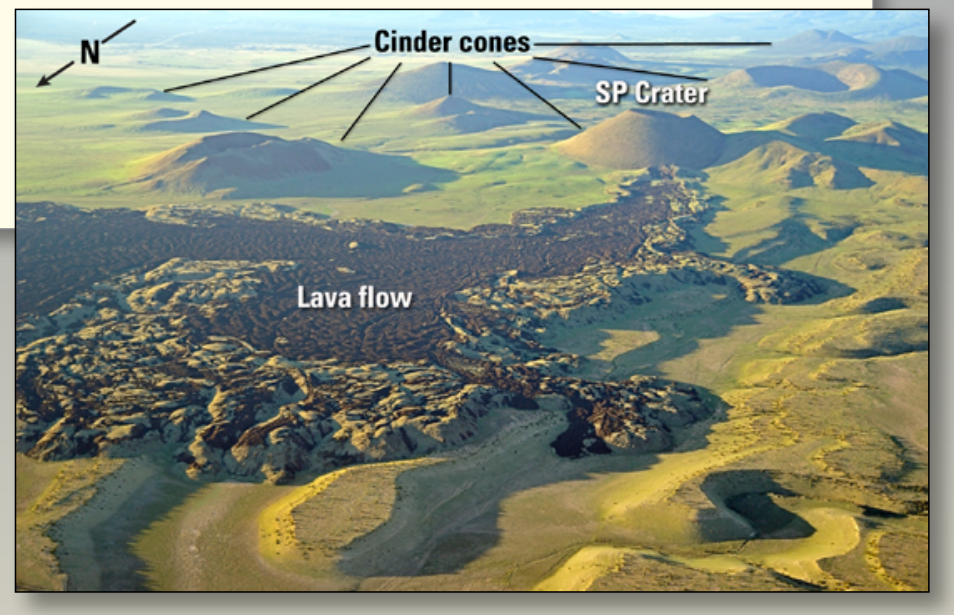




\section{Lahars Travel Rapidly Down Valleys Like Rivers of Flowing Concrete}

Lahars are mud or debris flows containing soil, rock, and water that originate on the flanks of a volcano. A lahar resembles a slurry of wet, flowing concrete as it rushes down narrow valleys at speeds as great as $40 \mathrm{mi} / \mathrm{hr}$. Close to their source, lahars are torrents that can rip up and carry trees and car-sized boulders. When a lahar reaches flatter terrain, it loses speed, spreads, and leaves a layer of mud over a broad area. Lahars can bury agricultural land and sweep away bridges, roads, or entire towns, entombing everything where deposits settle.

Lahars are a major hazard at volcanoes with glaciers, crater lakes, or significant runoff from precipitation. When a volcano erupts, hot rocks can mix with meltwater and (or) surface water to form lahars. During intense rainfall, flowing water scours barren volcanic deposits and may form lahars that transport debris far down river valleys. For decades after lahars come to rest, rivers erode the deposits and transport rocks and mud downstream. The excess sediment fills channels and repeatedly forces water to flood beyond river banks. Constricted and sedimentladen rivers devastate aquatic habitats and clog shipping lanes.

Although lahars commonly reach tens of miles from their source, they can extend more than 100 miles. Even when a volcano is quiet, smaller events can occur seasonally during heavy rainfall, with damage mostly limited to stream channels.

\section{Volcanic Slopes Can Collapse Even Without an Eruption}

Volcanoes are susceptible to landslides because their steep slopes are made of numerous overlapping layers of lava flows, loose rock rubble, and ash. Hot, acidic groundwater can circulate and weaken volcanic rocks to the point that they transform into wet, slippery clay. The constant pull of gravity is always at work at volcanoes, and eruptions, intrusions of magma, fracturing by large local earthquakes, and intense rainfall can all contribute to the eventual collapse of volcanic slopes.

Volcanic landslides may occur during increased volcanic activity but also at other times without warning. When landslides move at high speed down slopes, they can break apart to form debris avalanches. Large debris avalanches may bury a river valley or the flanks of a volcano under tens to hundreds of feet of rock debris and create a chaotic landscape marked by small hills (hummocks) and pits. When mixed with sufficient water, landslides and debris avalanches can transform into lahars.

\section{Volcanic Gas Harms Human, Animal, and Plant Health}

Magma contains dissolved gases, the driving force of volcanic eruptions. Water vapor is the most abundant volcanic gas followed by lesser amounts of carbon dioxide $\left(\mathrm{CO}_{2}\right)$, sulfur gases, and other gases. At active volcanic systems, gases are released continuously from volcanic vents, fumaroles, springs, and even through the soil. Almost all volcanic gas dissipates harmlessly into the atmosphere, but there are exceptions.

$\mathrm{CO}_{2}$ gas is odorless and heavier than air. At actively outgassing volcanoes, it collects in concentrations that can quickly overcome and suffocate people and animals, especially within snow and earthen caves and in low-lying depressions.

Sulfur dioxide $\left(\mathrm{SO}_{2}\right)$ gas is lighter than air and when inhaled has a bitter taste. Emissions of large volumes of $\mathrm{SO}_{2}$ gas can lead to localized acid rain and more widespread volcanic smog (vog). Hazards associated with $\mathrm{SO}_{2}$ gas include acid-rain corrosion of metals and damage to plants. Vog is a significant health hazard for people, particularly those with preexisting respiratory ailments.

\section{Heated Ground and Hot Water Create Beautiful but Deadly Scenery}

Volcanoes in areas with ample groundwater host hot springs, geysers, and other beautiful hydrothermal features - like those of Yellowstone Caldera in Wyoming. The ground surface in thermal areas can be slippery or covered with a thin breakable crust that overlies scalding fluid. Physical contact with hot springs and thermal features can cause severe burns, and submersion is potentially deadly. Hot springs have injured or killed more people in Yellowstone National Park than any other natural feature, including encounters with wildlife.

Underground, hot water can become so pressurized that it reaches temperatures above its boiling point. Shifts in a hydrothermal system can cause sudden pressure changes that make water burst into steam and violently expel rocks and hot water as a hydrothermal explosion. These can occur without any prior sign of disturbance. Such explosions can excavate shallow craters more than 1,000 feet wide and hurl large rocks hundreds of feet.

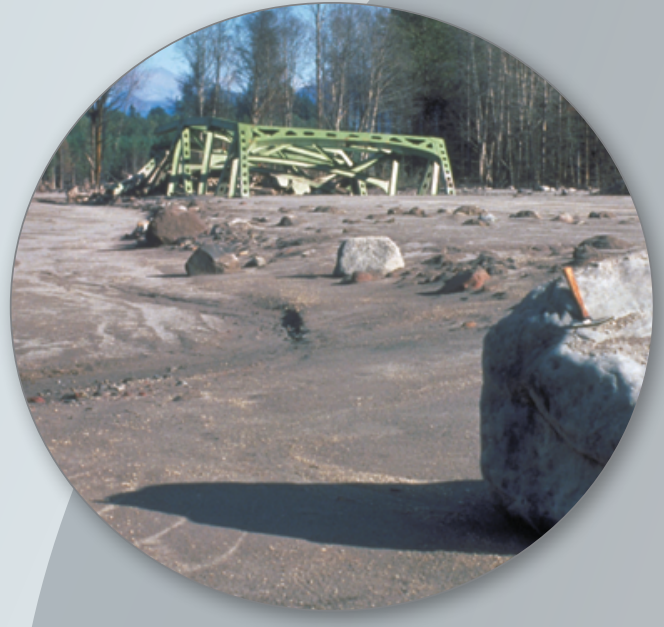

On the morning of May 18, 1980, the eruption of Mount St. Helens, Washington, caused massive lahars that choked rivers with sediment. This bridge was carried one-third of a mile downstream and partially buried along with large boulders that were also transported by the lahar. (U.S. Geological Survey photograph by Richard Waitt.)

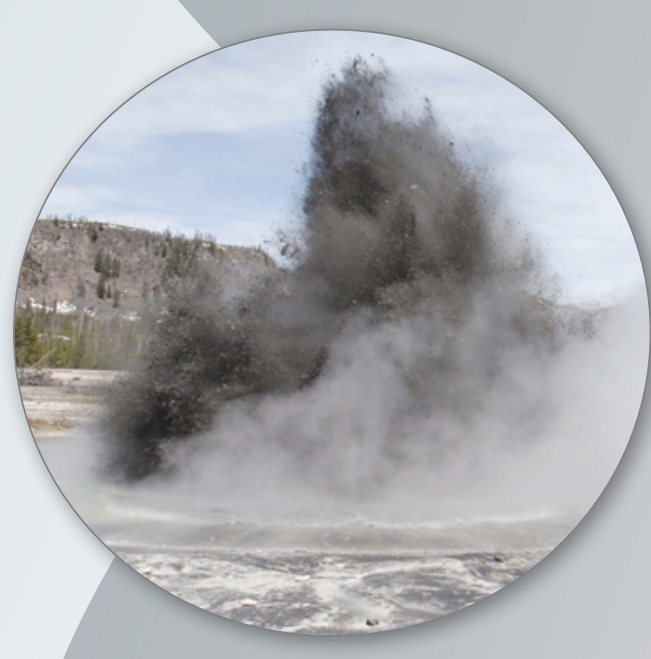

Hydrothermal explosions are common in Yellowstone National Park. Here, steam and pulverized rock blast from a hot spring in Biscuit Basin on May 29, 2009. In the 1880 s and early 1890 s, a series of powerful explosions and geyser eruptions ripped through the "plumbing" system beneath Excelsior Geyser in the Midway Geyser Basin. Large rocks were hurled as far as 50 feet. In 1989, at Porkchop Geyser in Norris Geyser Basin, an explosion ejected an apron of rock debris 15 feet across. (Photograph courtesy of Robert Smith, University of Utah.) 
